\title{
MONGOLIAIN NORTHEAST ASIA: ISSUES OF SECURITY SURVIVAL AND DIPLOMACY: MONGOLIA'S PLACE IN ASIA TODAY
}

\author{
By Robert E. Bedeski, Ph.D.(Canada)
}

\begin{abstract}
:
With the collapse of the Soviet Union, Mongolia lost its twentieth century protector, and has had to navigate Asian and global politics at a time when China is becoming a dominant economic and military power. Chinese economic and demographic expansion will directly impact Mongolia and the precedent of the sinification of Inner Mongolia demonstrates new challenges to the isolated Mongolian Republic. Energy imports, military security, trade opportunities and investment climate are closely affected by China, and Mongolian diplomatic efforts must take the southern giant into primary consideration.
\end{abstract}

\section{Geostrategic background}

Centuries before the Qin dynasty unified the Chinese empire, the Han peoples had an uneasy relationship with the nomadic herdsmen and warriors of the northern frontiers. Local kings constructed walls to protect their territory from incursions. The Great Wall remains as the historical frontier established by Qin Shi Huangdi in 221 BC to keep out the precursors of Mongolians. Han emperors made alliances with far-off kingdoms to "use barbarians to control the barbarians." (Yi yi zhi yi) After each major dynasty, central Asian tribes expanded at the expense of China, and often adapted Chinese technology and institutions, as well as intermarried and assimilated into Han culture. The Mongol conquests in the twelfth and thirteenth centuries incorporated China into the largest empire ever seen, and left subsequent Chinese states with historical precedent that the northern frontier would always remain their Achilles heel.

During the Qing dynasty (1644-1911), Russian and Manchu overlords jousted with each other, with the Korean Peninsula as the eastern anchor of the long frontier. Mongolia emerged as hapless buffer between the expanding Russian and Chinese empires - not unlike Poland between Germany and Russia in Eastern Europe. The decline of Qing was accompanied by Han migrations into Mongolia, a scramble for concessions, wars over who would succeed Beijing as the hegemonic power in East Asia, and incorporation of the heretofore unimportant (in a strategic sense) coastal regions into the global trade network. 
Guangzhou, Shanghai, Qingdao, Dalian, Xiamen, and Tianjin all emerged as new commercial and industrial cities, serving as entrepots between China and the West, while Japan entered the ranks of the industrial Great Powers.

Similar to France, China has its two frontiers - continental and maritime. But unlike France, China's maritime frontier was activated largely in the past century and a half. Prior to the impact of the West, practically all Chinese strategic attention was focused on inner Asia. With the industrial revolution and Western global expansion, China faced new threats - shrinking traditional insecurities by comparison. Simultaneously, though separately, the Chinese and Russian empires crushed and absorbed central Asian societies into themselves. Since the mid-nineteenth century, China was concerned largely with the threats from the West and Japan. In no small part, the Chinese Communist revolution succeeded because the Guomindang failed to stop the Japanese, and was fueled by the promise of saving the nation from Western, and then Soviet, domination.

After the 1917 Russian revolution, Mongolia became a pawn in SinoRussian relations. The first decade of the People's Republic of China (PRC) saw a period of Sino-Mongolian friendship, with aid and cooperation. During the Cultural Revolution, relations deteriorated, as they did with Russia. Since the mid-1980s, as China repaired relations with Russia, Mongolia was welcomed with a warm embrace.

\section{A Comprehensive Approach to Security: Co-existing with China}

Today Mongolia is primarily concerned with national security and has adopted a comprehensive, rather than strictly military, approach. When Mongolia ended her satellite relationship with the Soviet Union (March 1990), the urgent priority was - and remains - to maintain national sovereignty through security. From that time, Mongolia started reviewing its foreign and internal policies and priorities and in 1994, the Mongolian parliament adopted three important documents: concepts of national security, of foreign policy and military doctrine. The national security concept reflected the country's geopolitical situation and role, and specifically defined Mongolia's vital national interests as well as the means of ensuring them. The five vital national interests are:

a) existence of the Mongolian people and their civilization,

b) the country's independence, sovereignty, territorial integrity, inviolability of State borders, 
c) relative economic independence,

d) sustainable ecological development and

e) national unity.

All other interests are subordinate to them. ${ }^{1}$

The "Concept of National Security of Mongolia"2 states that

The vital national interests of Mongolia are the existence of the Mongolian people and their civilization, the country's independence, sovereignty and territorial integrity, inviolability of State frontiers, relative economic independence, sustainable ecological development, and national unity. The vital national interests of Mongolia constitute the object of special care and protection on the part of the State and the people.

National security includes the following topics in the document:

To this writer, this represents a model operationalization of the concept of human security, which has so far been more theoretical than actual:

- Security of the Existence of Mongolia

- Security of Social Order and State System

- Security of Citizen's Rights and Freedoms

- Economic Security

- Scientific and Technological Security

- Information Security

- Security of Mongolian Culture and Way of Life

- Security of the Population and Its Gene pool

- Ecological Security

While armed military forces exist, national security has a much more diffuse approach - that of human security. Mongolia realizes it cannot hope to halt major aggression with military force, especially without allies, and must therefore adopt a broad plan to survive. Its approach is embodied in the "Concept" document, and has similarities with Switzerland.

The document "Fundamentals of the Military Doctrine of Mongolia" puts forward the need to conformity with universally recognized principles of international law, and in particular Mongolia discards the use of force or the threat to use force as a means of settling disputes. Furthermore it will not participate in wars and conflicts unless it falls victim to foreign aggression. Mongolia shall fulfill her UN Charter obligations and support UN activities.

\footnotetext{
${ }^{1} \mathrm{http}: / /$ www.un.int/mongolia/natsec.htm

The translated document is available at http://www.extmin.mn/ concept_of_national_security_ofm.htm
} 
Mongolia will not be part of any Military alliance unless the independence and sovereignty of Mongolia is directly threatened, and will strictly adhere to the policy of not allowing foreign troops to enter, be stationed in or pass through the national territory in the absence of relevant Mongolian legislation. ${ }^{3}$

\section{National security - the territorial dimension}

Geography has influenced Mongolia's destiny. The country is bordered on the north by Russia, and was a satellite of the Soviet Union for nearly 70 years. With Soviet collapse, troops were pulled out, leaving garrison sites as virtual ghost towns, with unknown toxic and possibly radioactive waste dumps. Post-Communist Russia continues to exercise economic influence. When Russian fuel supplies declined, exports to Mongolia were stopped - the only source for them. In 2000, Mongolia began to import fuel from China in small quantities. Too great dependency on China for anything as strategic as energy would only trade one patron for another.

Mongolia has a $4776 \mathrm{~km}$ border with China's Inner Mongolia and Xinjiang. This long boundary has been relatively stable since the 1920s. The last military aggression against Mongolia was in the 1939 Khalkh Gol War when a Japanese attack was beaten back with major Soviet assistance, preventing incorporation into Manchukuo and Korea. Soviet Russia and Mongolia had signed a joint treaty of support on March 12, 1936, and in July 1939, 38,000 Japanese troops attacked with artillery, tanks and planes, outnumbering the defenders in artillery and troops by a factor of three, and 4.5 times the cavalry. The Mongolians and Russians had an advantage in tanks, and the battle of Bayantsagaan cost the Japanese heavily. ${ }^{4}$ A tall memorial, visible from most parts of Ulaanbaatar, commemorates Soviet wartime assistance. Today, there is no longer Russian military support for Mongolian territorial integrity, although a cooperative relationship exists. ${ }^{5}$

Management of long borders with its two neighbors has been an ongoing concern. The frontiers are sparsely populated, and relatively open. Maintaining control of borders is a vital part of preserving Mongolian sovereignty. Under joint agreement, inspection of border markers has been underway. China and

3 "Mongolia’s Military Doctrine and Legislation“, http://userpage.fu-berlin.de/ corff/ $\mathrm{im} / \mathrm{Buch} /$ WhitePaper-4.html

4 Mongolian Messenger, 990908,8

${ }^{5}$ Border problems of smuggling and cattle rustling have become irritants on the Mongolia-Russia border. A joint Conference was held in Irkutsk on February 18, 2000 to address these concerns. Mongolian Messenger, March 2, 2000, p. 2. 
Mongolia signed a 1964 protocol to have border inspections every five years. Full checks occurred in 1984, and took over two years. Many markers and stations were reported in disrepair ${ }^{6}$, and recently, another review of the border was completed in 2004.

\section{Mongolia faces China}

Mongolia's emergence as a fully independent modern nation-state was retarded for seventy years as a protectorate of the Soviet Union. The national security concept of Mongolia changed dramatically after the end of the Cold War and the complete withdrawal of Soviet troops in 1992 from Mongolia's territory. While Mongolia used to serve as a buffer state between China and Russia during the Cold War, the Mongolians participated in the defense system of the Warsaw Pact States acting as the Eastern frontier, effectively shielding the former Soviet Union from direct contact with her estranged former comrade, the People's Republic of China. China was regarded the enemy, a threat not only to the USSR but also to Mongolia. It was the mission of the Mongolian army to build up armaments and the number of military personnel to a level sufficient to carry out joint operations with the Soviet armed forces. ${ }^{7}$

With the collapse of the Soviet system, Mongolia seized its sovereignty and set up a democracy. At the same time China has been developing into a global power based on authoritarianism and a dynamic market economy. Russia prefers Mongolia to remain as a sovereign buffer state between itself and China, but is in no position to help in a crisis.

Mongolia's dilemma is geopolitical: First, geography renders it vulnerable to its two very large neighbors. Second, when either neighbor is expanding, Mongolia is directly affected. In the Soviet period this meant incorporation into the Communist ideological, political, military, and economic system. During the first decade of the PRC, the Sino-Soviet alliance insured that the Sovietimposed status quo in Inner Asia would remain intact. With the rift between Moscow and Beijing, Mongolian relations with China also deteriorated. With the re-normalization of Sino-Russian relations, Mongolia has followed suit. But while the two giants enjoy rough equivalence in national power, Mongolia has no such luxury, and must navigate its diplomacy with extreme caution.

${ }^{6}$ Mongolian Messenger, 5 May 1999, p. 8.

7 "Security Issues and the National Defense Concept", http://userpage.fu-berlin.de/ $\sim$ corff/im/Buch/WhitePaper-3.html 
Chinese strategists see the integration of economic and security interests as a key development in the post-Cold War era. With Deng Xiaoping's 1978 reforms transforming the Chinese economic system from centrally-planned socialism into a market-oriented economy, growth has been significant. Western analysts, businesses and politicians optimistically anticipate that this economic growth will generate a new middle class and pressures for democratization. A more realistic view is that China pragmatically views economic growth as the central component to increasing national strength. The demise of the Soviet Union as protector and underwriter of Mongolia has given China an opening on its northern frontier to expand its influence over a critical historical buffer.

Mongolia's new independence, with a market economy and intense national pride, faces a dynamic Chinese economy and few alternative partners for trade and investment. In 2001, 53.7 \% of Mongolia's exports were to China, followed by $22 \%$ to the U.S. and $10.3 \%$ to the Russian Federation. ${ }^{8}$

\section{The cashmere industry: Chinese economic penetration?}

One example of China's penetration into the Mongolian economy is the cashmere industry. In the years 1991-96, Mongolia had a trade surplus, but 1997 saw a $\$ 38$ million deficit, reflecting a growing dependency on China. Unprocessed raw materials occupy up to $90 \%$ of exports to China. Cashmere, a major cash product, depends on the China market. Around $40-60 \%$ of basic food commodities, such as flour, rice \& sugar, are imported from China.

The case of Mongolia's cashmere industry illustrates how economics can be a weapon of Chinese national interest, at the expense of a neighboring state. The cashmere industry has been a test case for Mongolia-China economic relations, and Ulaanbaatar cannot be too optimistic. In 1998, the industry accounted for $15 \%$ of GDP, directly, and indirectly employing around 10,000 workers. Chinese merchants began paying higher prices for the raw cashmere, which was then sent to China for processing. After significant investment in processing equipment, Mongolia saw supplies severely decrease, causing extensive layoffs. Critics feared a Chinese agenda to take over Mongolia's 30\% of world market and create a monopoly by driving Mongolian processors out of business. They pointed to the state-owned China Agricultural Bank providing interest-free loans to 22 Chinese cashmere companies as evidence. Apologists say the Chinese are simply better businessmen.

\footnotetext{
${ }^{8} \mathrm{http}: / /$ www.investmongolia.com/m6.htm
} 
Mongolia produces average of 3,500 tons of cashmere annually, or $30 \%$ of the world total. Of the 46 companies involved in purchasing and processing cashmere in Mongolia, 22 were Chinese, and an investigation in May 2000 indicated that 15 of these were not in conformity with law the requires processing in Mongolia to qualify for a tax exemption. Also, some companies operated in Mongolia without legal registration. Another problem for the Mongolian processors is that they were paying US $\$ 35-38$ versus Chinese prices of $\$ 40-42$ per kilogram. A similar situation is emerging in the trade in wool and sheepskins, with Chinese higher prices removing a raw material from the country. China procures $67 \%$ of the global cashmere output (15,000 tons) compared to Mongolia's 21\%.

In early May, 2000 the government of Mongolia imposed a temporary moratorium on the export of raw cashmere, since native companies were laying off employees for lack of material. This appears to violate rules of the WTO, which Mongolia joined in 1995. The Multifibre Arrangement will end in the next few years, with expected flight of textile factories from Mongolia ${ }^{9}$. In 2001, the government privatized Gobi Joint Stock Company, and purchased about 75\% of its stock. It is an integrated company that procures processes, manufactures and distributes cashmere products, with $80 \%$ of its output sold to the European Union, the United States, Japan, and Russia. ${ }^{10}$

\section{Land reform - privatization}

Another key political issue was land privatization. A major concern was that once land became a commodity, Chinese investors or their fronts would purchase property and become de facto landowners of Mongolian real estate. A law on land was passed in June $2002^{11}$, and reserved ownership to Mongolian citizens, companies and organizations. Under article 6.3,

Foreign countries, international organizations, foreign legal entities, foreign citizens and stateless persons may become users of land for a specific purpose and a specific time period subject to contract conditions and in compliance with the law.

On 1 May 2003 the law on land ownership came into force. It meant that for the first time in the country's history, Mongolian citizens were entitled to own land. The government, under pressure from the opposition party and its

\footnotetext{
${ }^{9}$ Far Eastern Economic Review, June 24, 2004, 48.

${ }^{10} \mathrm{http} / / /$ www.spc.gov.mn/english/companies/gobi/gobi_marketing.htm

${ }^{11} \mathrm{http}: / /$ www.mongolembassy.org/doc/law_of_mongolia_on_land.doc
} 
supporters, passed the legislation in order to modernize the economy and provide a source of collateral for financial expansion. However, fears still remain that foreigners may take advantage to buy property assets.

\section{Foreign Investment ${ }^{12}$}

Another area of sovereignty concern is foreign investment. The major legislation was passed in 1993. ${ }^{13}$ In 2000, Mongolia's Foreign Investment and Foreign Trade Agency oversaw more than 1400 foreign corporations from 53 countries. There are 483 joint and single Chinese enterprises in Mongolia in mining, service, agriculture, and light industry. Under law, a Joint cooperative enterprise requires minimum of US $\$ 10,000$, and one person could own multiple companies. Most Chinese companies are small, and a re-registration of foreign companies in 1999 revealed that nearly $50 \%$ of them were in non-compliance with the law.

Mongolia increasingly depends on the dynamic Chinese economy, and the government hopes that other foreign countries can invest here for diversification. The government emphasizes mining, agriculture, and tourism. Before 1991, much food was raised in Mongolia, but with privatization and loss of state subsidies, domestic food production suffered.

Foreign investment has risen from US $\$ 965,000$ in 1990 to $\$ 350$ million in 1999 , with nearly $70 \%$ in geology, mining and prospecting. In the past ten years, $26 \%$ of foreign investment came from Hong Kong, with $18.8 \%$ from China, $6.7 \%$ from Korea, $5.6 \%$ U.S., and $4.5 \%$ Russian. ${ }^{14}$

In December, 1998 President Bagabandi visited China - the highest level visit by a Mongolian official to China since Tsedenbal in $1962 .{ }^{15}$ China agreed to provide soft loan credits of US\$12 million to Mongolia, and there were talks on the gas pipeline from Russia through Mongolia, as well as a $\$ 39.7$ million deal to build Mongolia's first oil refinery. Since 1990 through 1998, Chinese traders invested \$60 million in Mongolia. In 1994 the two countries signed a new treaty defining bilateral relations. At the time, trade with China occupied $30 \%$ of Mongolian foreign trade, and trade in 1997 was five times that of $1990 .^{16}$

\footnotetext{
${ }^{12}$ Interview with J. Chin-Erdene, Foreign Investment and Foreign Trade Agency- see entry in Outlook/Contacts/China.

${ }^{13}$ For text of the law, see http://www.indiana.edu/ mongsoc/mong/invest.htm

${ }^{14}$ Mongolian Messenger, February 23,2000, p. 4.

${ }^{15}$ Mongolian Messenger, 981216, 3

${ }^{16}$ Mongolian Messenger, 981216, 3.
} 
It was hoped that the Russia-China gas pipeline (a US\$10 billion project) could spur Mongolia development. However, the Chinese insisted that the Angarsk line bypass Mongolia, even though it was more expensive. There is also the problem of relatively little infrastructure or experience in Mongolia. Increased importation and use of gas might sacrifice Mongolia's established coal industry $-13,000$ coal miners could lose jobs. ${ }^{17}$ Moscow has been shifting its plans, and recently favored an all-Russian route to Nakhodka, for the benefit of Japan. The gas and oil pipeline was still under negotiation in late 2004, and could be critical for Mongolia as a "transit country". ${ }^{18}$

\section{The demographic dimension}

Chinese emigration is increasingly a strategic issue. ${ }^{19}$ According to Tsedendamba Batbayar, ${ }^{20}$

Although after 1990 Chinese-Mongolian relations have improved significantly, Chinese economic and social influence has been gradually and (for the Mongolians) worrisomely increasing, which is demonstrated in a privatization bill in the national legislature shelves fearing loopholes allowing foreigners (i. e. Chinese) to acquire land through local parties. China has a huge population of some 1.3 billion to Mongolia's 2.5 million. The neighboring Inner Mongolian Autonomous Region has a population of some 20 million to Mongolia's 2.5 million. At any time some 100 million people are on the move in China seeking a better life within the country, from rural to urban areas, in search of employment or new opportunities abroad. China's population density is 127 times greater, making Mongolia seem like a land of frontier opportunity for some Chinese. Mongolia has difficulty in defending itself from Chinese influence on a variety of fronts from imported goods, foodstuff, to business and investment, intermarriage and illegal immigration or settlement. So both countries are opening their economies to freer trade, but at a price that threatens Mongolian cultural identity and economic independence.

Border control is a vital part of comprehensive security to prevent smuggling and illegal migration - a growing problem throughout the world. But a more crucial issue is the dynamics of demography for Mongolia. Harsh

\footnotetext{
${ }^{17}$ Mongolian Messenger, 991110, 7

${ }^{18}$ The term was used by President Bagabandi in his remarks at University of British Columbia on October 25, 2004.

${ }^{19}$ Smith, Paul J. "The Strategic Implications of Chinese Emigration." Survival. (36:2, Summer 1994)

${ }^{20}$ Foreign Migration Issues in Mongolia, www.un-mongolia.mn/undp
} 
climate and topography will limit Mongolia's population. About 27\% of approximately 2.5 million Mongolians live in Ulaanbaatar. Registration for residence there costs citizens Tugrik 26,000 for adults, and 13,000 for children. ${ }^{21}$ A Centre for Civil Registration centralizes and coordinates citizen registration, issuing certificates and passports. Acquisition or loss of citizenship is no easy matter - only four persons were granted citizenship in 2001 - a process that requires approval of the national President.

In 1994, the government established the Council of Foreigner Affairs under the Ministry of Justice, to supervise foreigners living in Mongolia. By 2002, it had deported 41 persons, and denied 30 residence privileges. The Council has fifteen members, including top representatives from the Ulaanbaatar municipal government, intelligence, border guards, central police, the Foreign Ministry, customs service, the Foreign Investment Board, and the Council on National Security. It reports annually to the President.

The Hural (legislature) annually sets limits on the proportion of foreign residents. Under the 1994 citizenship law, no more than $1 \%$ of population can be foreign and $0.33 \%$ (of the total national population) of any one nationality. Mongolia also tries to discourage Mongolians from emigrating or becoming foreign citizens. An official breakdown of foreign residents indicates around 1,520 Chinese, 1,493 Russians, with 7,554 in other categories, including stateless, and short or long term temporary permits. This works out to $0.4 \%$ foreigners, well below the Hural limits, although one must always allow for under-counting. Mongolia demographers indicate country could support 4-5 m people. Ulaanbaatar family's average 2.4 children, rural families have 3.1 , so population is still growing while almost prohibiting immigration.

\section{Foreign residents}

Relations with China were poor in the 1970s and early 1980s; Mongolia criticised China's treatment of its Mongolian citizens and was in turn accused by Beijing of seeking to expel its estimated 7,000-person Chinese community. In 1984, the Mongolian Government expelled 1,700 Chinese, but did not bother assimilated ethnic Chinese citizens. The animosity may account for the absence of any reference to a Chinese minority in the 1989 census. A more recent source indicates that there are 35,000 Chinese in Mongolia. Mongolian police have arrested illegal immigrants from China (including ethnic Mongolians from Inner Mongolia), some of whom were carrying false Mongolian passports.

\footnotetext{
${ }^{21}$ Mongolian Messenger, 990217,6
} 
Mongolia does not recognize dual citizenship, and foreigners retain their original passports. Prior to 1990, Mongolia had a large population of Soviet engineers and other specialists working under contract in Mongolia, plus an estimated 55,000 Soviet troops, but they were always viewed as "helpful foreigners" and not included in Mongolian census figures. Although since 1920, many Russians have settled in the Tannu Tuva and Buryat Mongol regions of Siberia across the border from northern Mongolia, there has been little Russian migration to, and settlement in, Mongolia. Agreements reached in March 2002 between the Russian and Mongolian Governments mean that, in theory, nationals of each country resident in the other country can use the other country's healthcare system. Moscow claimed that Mongolia owed about US $\$ 10$ billion, and has agreed to settle the debt after payment of $\$ 250$ million in 2003, which boosted Mongolian credit.

\section{Conclusion}

At the end of the Cold War, with the collapse of the Soviet Union, democracy was predicted to be the dominant form of government, international prosperity would be globalized through the spread of trade and technology, and peace would be preserved through multilateralism and UN leadership. Those promises have turned sour, with African economic backsliding, Islamist fundamentalism, U.S. hegemonism, and the dysfunctionality of the U.N. Mongolia was to be a beneficiary of the "New World Order", but faces a longterm challenge to its survival - not because of broken promises, but rather as the unforeseen result of the radical transformations of China and Russia. Her seventy year accommodation with the Soviet Union provided protection within the Warsaw Pact and Comecon, and now she is on her own, facing the Chinese demographic and economic giant relatively alone.

Russia has her own problems and is not seen as a solution to Mongolia's security problems. Through diplomacy, Mongolia has sought to maintain her non-alignment, so far declining to join the Shanghai Cooperation Organization (SCO), an intergovernmental international organization founded in Shanghai on 15 June 2001 by six countries, China, Russia, Kazakhstan, Kyrgystan, Tajikistan and Uzbekistan. Its member states cover an area of over 30 million $\mathrm{km}^{2}$, or about three fifths of Eurasia, with a population of 1.455 billion, about a quarter of the world's total. Its working languages are Chinese and Russian. ${ }^{22}$

${ }^{22}$ http://www.fmprc.gov.cn/eng/topics/sco/t57970.htm 
One of the expectations of the New World Order was that state sovereignty would become obsolete, with a global regime of international law, multilateralism, NGOs, and the UN as watchdog of human rights. Mongolia saw this vision dissolve, and is absolutely committed to preserving her national sovereignty through human security and international diplomacy. Despite small population and a smaller military establishment, Mongolia has sent peacekeepers participate in the US-led expedition in Iraq, and hosts a U.S. military mission, which provides 90 percent of foreign military training and assistance. ${ }^{23}$

For Mongolia, the sovereign nation-state is not obsolete - an informal alliance with the U.S. may be the most effective means of surviving in a location of extreme vulnerability. At the same time, Mongolians will have to firmly yet politely draw the line between themselves and China to avoid the fate of absorption that has taken place in Inner Mongolia. For Canada, these realities must remain uppermost in our relationship with both countries. Despite Mongolia's risky existence, Canada can contribute to the survival of a state, people and civilization which made major contributions to the early globalization of humanity through development assistance, cultural and educational links, investment, and diplomatic supports. As President Bagabandi said in Vancouver in 2004, both Canada and Mongolia are in bed with elephants - his country's dilemma is that there are two, while Canadians only have to worry about one.

${ }^{23}$ Robert Kaplan, "The Man Who Would Be Khan”, The Atlantic Monthly, March 2004, http://www.theatlantic.com/doc/prem/200403/kaplan 